\title{
Network approaches and strategic management: Exploration opportunities and new trends
}

\author{
Beata Barczak ${ }^{1}$ (D), Tomasz Kafel2 (iD, \\ Pierpaolo Magliocca ${ }^{3}$
}

\begin{abstract}
PURPOSE: The analysis of the literature shows that the attempts to conceptualize the strategic aspects of the network bring a significant impact on the development of research on organizational networks. This article aims to analyze the new trends in strategic management, and in particular on the possibility of exploring the network approach in strategic management, through the existing literature and the presentation of the new contributions of the following articles published in the current issue. METHODOLOGY: The article is descriptive in character; thus it is based on a literature review and its constructive critics. A narrative literature review was used to present the main assumptions and features of the network approach in strategic management, along with an indication of emerging trends and new directions. Also the identification of theoretical foundations for understanding the processes of strategic change in inter-organizational networks and the proposition of the way to understand network strategy were presented. FINDINGS: The research included in this issue shows that from a network perspective, business strategy plays an important role in guiding the development of individual relationships and networks. Exploring the network approach in strategic management allows one to adopt the category of network strategy, which can be described through the coexistence of cooperation and competition. IMPLICATIONS FOR THEORY AND PRACTICE: Considerations lead to the conclusion that the business strategy must be expressed in terms of potential changes in the network in which the company operates, taking into account its

\footnotetext{
1 Beata Barczak, Ph.D., Hab., Associate Professor, Department of Management Process, College of Management and Quality Sciences, Cracow University of Economics, Rakowicka 27, 31-510 Kraków, Poland, e-mail: barczakb@uek.krakow. pl (ORCID ID; https://orcid.org/0000-0003-0345-2267).

2 Tomasz Kafel, Ph.D., Hab., Associate Professor, Department of Organization and Management Methods, College of Management and Quality Sciences, Cracow University of Economics, Rakowicka 27, 31-510 Kraków, Poland, e-mail: kafelt@uek.krakow.pl (ORCID ID: https://orcid.org/0000-0003-2931-1921).

3 Pierpaolo Magliocca, Associate Professor, Department of Humanities. Literature, Cultural Heritage, Education Sciences, University of Foggia, Via Arpi 176 - 71121 Foggia, Italy, e-mail: pierpaolo.magliocca@unifg.it, (ORCID ID: https://orcid. org 0000-0002-4954-1495).
} 
current and selected position in the network. Despite the fact that the current state of research on organizational networks in the theory of strategic management shows that this approach is already quite well established, on the basis of the analysis of research results concerning the conceptualization of strategic aspects of the network, the existing problems and limitations were identified. ORIGINALITY AND VALUE: The main problems related to the exploration of the network approach and the resulting consequences for the definition of the network strategy were indicated. Also, the combination of an organizational and economic approach with the logic of competitive advantage and relational annuity. The demonstration that the network perspective in strategic management allows for a more complete understanding of the strategic behavior of modern enterprises.

Keywords: network, network strategy, network approach, strategic management

\section{INTRODUCTION}

In today's changing competitive environment, enterprises, traditional markets, and hierarchical organizations are partly replaced by inter-organizational networks (Achrol \& Kotler, 1999; Gulati, Nohria, \& Zaheer, 2000: Håkansson \& Ford, 2002; Möller \& Halinen, 1999: Ring \& Van de Ven, 1992; Wang, Chen, \& Fang, 2021). Inter-organizational networks have become a way of describing the new reality created by complex social, economic, and technological changes. The accelerator in this process is the technological factors taking the form of the fourth industrial revolution (Industry 4.0) (Barczak, 2016, 2020; Wang, Yang, \& Guo, 2021). Along with the development of the network concept, the so-called network approach was developed, which emphasizes the importance of the whole company's contacts with the environment, forming an extensive network of connections.

Modern research indicates a wide range of possibilities for exploring the network approach in the field of strategic management. The shift towards increasingly networked business environments raises the question of whether current strategic management theories still offer the right picture of business strategy. Traditional theories of strategic management place great emphasis on gathering and controlling resources within one company. However, adopting a network perspective points to the need to establish external relationships to gain access to resources (Tikkanen \& Halinen, 2003; Baum \& Rowley, 2008). The logic of strategy based on a traditional approach is no longer applicable in a reality where organizations are increasingly linked and networked. These organizations compete and cooperate at the same time, they are forced to reorganize their resources constantly, and their boundaries are blurred. This is reflected in the increasingly accepted economic practice 
paradigm of the network economy or the economy of sharing. Today, we are even talking about a network society (Castells, 2010).

The dynamic development of the concept of inter-organizational networks has put management theorists, who previously analyzed the relationships between actors in dual systems, before a series of completely new and so far insufficiently described and explained problems, relating to the nature, sources of competitive advantages, and conditions of effectiveness of network structures.

This article aims to analyze the new trends in strategic management, particularly the possibilities of exploring the network approach in strategic management, through the existing literature and the presentation of the new contributions of the following article. The starting point is the discussion of the evolution of strategic management and the network approach, which allowed to indicate the limitations and basic research areas in the field of exploring the network approach in strategic management, as well as to present the contribution of the articles in this issue to the discussion on the possibilities and directions of the network approach development in strategic management. We also pay attention to neostrategic management as a concept that points to networking the organizations as a way to solve enterprises' problems in the 21st century and the possibilities of obtaining a synergy effect in designing the organizational network through the integration of digitization, sharing economy, or a friendly ecosystem.

We use a narrative literature review to present the main assumptions and features of the network approach in strategic management and indicate emerging trends and new directions. The contribution of this article is to identify the theoretical foundations for understanding the processes of strategic change in inter-organizational networks and to propose a way to understand network strategy as a dynamic and emerging process that makes it possible both to manage the development of inter-organizational relationships and networks and to remain under their influence.

In this continuous process, the formulation and implementation of the strategy becomes an inseparable and integral part of relationship management. It has been pointed out that networks are unique, valuecreating constellations of resources and competences, and companies can act both to adapt to the requirements of the network and to changes and external stimuli. In particular, the article describes the possibilities of exploring the network approach in strategic management, pointing out significant problems and limitations in this area. 


\section{LITERATURE REVIEW}

\section{The development of strategic management concepts}

The achievements of strategic management are continuously enriched by the current research results in economics and, above all, in the management sciences. The following diversification in this field, which we are witnessing today, dates back to the 1980 s, when economics, organizational sociology, and political science-oriented fields began to develop. New theories have also emerged, such as: transaction cost economics, agency theory, contemporary game theory, evolutionary economics, resource theory, resource dependency, organization ecology, new institutionalism (Rumelt, Schendel, \& Teece, 1994).

A significant influence on the way the strategy was perceived was the development of the resource approach, which directed the researchers' attention towards the resource matching of many organizations in order to gain an advantage due to the configuration of resources and the ability to use them efficiently. In addition, theoretical perspectives such as evolutionary or networking perspectives have emerged. The ambition to analyze phenomena at the level of entire populations, not just individual organizations or their pairs, is reported. The evolutionary approach recognizes acceptable strategies in business ecosystems (Mouzas \& Henneberg, 2008; Wang, Chen \& Fang, 2021). By focusing on interdependence with other organizations, it imposes a dual obligation on the strategist to take the most favorable position possible in the business ecosystem and influence the coevolution of companies to maintain or increase benefits in the future (Czakon, 2017). The network perspective, on the other hand, has been developed by including more than one relationship, which is tantamount to expanding the research field beyond a single alliance, further beyond the portfolio of alliances perceived egocentrically by the company to the network structures in which it is embedded (Czakon, 2012). The focus of the researcher's attention shall be on a single relationship, a set of relationships by their characteristics, nodes by their characteristics, nodes by their position, and a set of network nodes by their characteristics.

The development of strategic management concepts is still progressing and we can see two dimensions in this transformation. The first of the dimensions is related to the emergence of subsequent, new strategic management concepts, which often hark back to the previous schools and approaches. The second dimension of development applies to the operationalization and adjustment of the previous concepts to the changing conditions. These changes have specific consequences, both for the strategic management process and the future research areas related to the strategic 
management concept. The contemporary conditions of business operations create new challenges for strategic management. These include, for instance, the use of dynamic capabilities in strategy building (Segal-Horn, 2004; Teece, 2007; Krzakiewicz \& Cyfert, 2014; Herhausen, Morgan, Brozović, \& Volberda, 2021), relational strategies (Zakrzewska-Bielawska, 2017), networking of organizations (Krzakiewicz \& Cyfert, 2013; Czakon, 2016), technology development and automation of processes (Schwab, 2016), global strategies (Porter, 1986; Gupta, Govindarajan, \& Wang, 2008). In view of these challenges, some researchers postulate the assumption of a new term: neostrategic management (Vrdoljak, Raguž, Jelenc, \& Podrug, 2016). According to their assumptions, the key disciplines shaping neostrategic management are strategic entrepreneurship, spiritual management, behavior strategy and cognition, and strategy as practice. Among the disciplines shaping neostrategic management, the authors of the term have also identified supplementary disciplines, such as entrepreneurship, cognitive and social psychology, spiritual and religion movements, sociology, and anthropology (Vrdoljak et al., 2016). In the proposed neostrategic management concept, its creators have addressed an important and valid problem of adjusting the strategic management concept to the new economic conditions of the 21st century. In this concept, particularly valuable is its link to the problems faced at present by the strategic management concept and an indication of the proposals to solve these problems. These solutions oscillate around such areas as networking the organizations, a multidisciplinary approach to strategic management, continuous improvement of strategy (in accordance with the idea of a learning organization), the enterprising nature of strategic thinking, and strategic group leadership (Vrdoljak et al., 2016; McGrath 2013).

The development of strategic management has also been significantly influenced by two factors (Schwab, 2016: Wang, Yang, \& Guo, 2021):

- the advent of the era of the knowledge-based economy (KBE), where information and knowledge are the key resources of an enterprise;

- the advent of the era of Industry 4.0, which assumes that companies will create global networks, including machinery, storage systems, and production facilities in the form of Cyber-Physical Systems (CPS).

To sum up, if we take an evolutionary perspective as a starting point, the development and evolution of strategic management can be presented in three eras (Venkatraman \& Subramaniam, 2002):

- firstly, the era in which strategy is seen as a business portfolio (traditional strategic management); 
- secondly, as a portfolio of opportunities (competency-based perspective);

- thirdly, as a portfolio of relationships (network approach to strategic management).

Each era presents a specific way of approaching strategic management and the formulation of that strategy. One can be tempted to say that the third era, strategy as a portfolio of relations, is still a poorly recognized area. It is a collection of fragmented ideas, not an established area in the field of strategic management. It is, therefore, also a rather amorphous perspective.

\section{Network approach}

In the literature on management sciences, one can notice enormous terminological diversity related to networks, probably resulting from the interdisciplinary nature of this concept. The heterogeneity in the perception and explanation of this issue results from the fact that the network ontology, not to mention epistemology and methodology, is only in the incubation and development phase. One may be tempted to say that the network concept is still amorphous, not thoroughly researched, and poorly structured. The aforementioned heterogeneity of the perception of the network is reflected in the multiplicity of definitions of organizational networks. A review of the literature in this area shows great cognitive value, and at the same time, confirms the multiplicity of views on network structures. An attempt at organizing various approaches and definitions of networks is the proposal to formulate the understanding of the network by researchers into three main approaches (Światowiec-Szczepańska \& Kawa, 2018):

1) Metaphorical - the term "network" is used as a metaphor for new organizational phenomena related primarily to the change of theoreticians' orientation from dyadic relations to a constellation, portfolio, or system of relations maintained by an organization. This approach largely corresponds to the phenomenon of strategic networks, strongly represented in management science theory. It also directly refers to the indirect form of coordination between the market and the hierarchy, which is the network.

2) Graphic - refers to an attempt to faithfully reflect the structure of connections within the enterprise or enterprises with other external entities. The aim here is a kind of "mapping" or "imaging" of the network (Abrahamsen, Henneberg \& Huemer, 2017; Czakon, 2017; Knoke \& Yang, 2020).

3) Mathematical - refers to the treatment of networks in mathematical terms, which focuses on the application of graph theory and mathematical 
tools to analyze network structures, often considered more important than the network context itself. An example is research in the field of complex networks, including small-world models or scale-free networks (Barabási, 2003; 2016).

The network approach has become more and more important in management theory and practice in recent years, and a multitude of studies related to networks and network approaches can be seen in the literature. As a new concept of cooperation between business entities, it was developed in the late 1970s as a result of technological changes in the business-tobusiness (B2B) market and increased international competition. It was then that the role of the company's contacts with its environment began to be noticed and highlighted, which formed an extensive network of connections. The 1990s brought an increase in interest in researching relations and links between companies. Breakthrough views in this area were presented by the IMP - Industrial Marketing and Purchasing Group. Among the creators of this model, Swedish researchers H. Hakansson, J. Jahanson, A. Lundgren, L.G. Mattsson and G. Easton (cooperating with Swedish researchers) have had major contributions. The Swedish model refers primarily to industrial markets, where there are networks of interconnected companies (Jahanson \& Mattson, 1993, p. 19). The basis of the model of industrial networks is formed by links in terms of entities, activities, and resources.

The network approach is based on the assumption that there are other participants in the exchange in commercial transactions, apart from suppliers and customers, creating various interdependencies. This creates a complex network of participants involved in various forms of exchange, having various effects on transactions and the state of relations between supplier and buyer, both during and between transactions (Sashi, 2021).

The achievement of this trend is to describe a business network model defined as a set of long-term formal and informal (direct and indirect) links (relationships) that exist between two or more entities (Hakansson \& Snehota, 1995; Wang, Chen, \& Fang, 2021). The Swedish school's work provides the genesis for a contemporary approach to networking and the basis for reflection on business networks and industrial districts, and cluster models.

The network approach defines the way of describing and analyzing reality (organizations, institutions, phenomena). The application of the aforementioned network metaphor allows the indication of the regularities that constitute research areas for the organization and management sciences. An interesting issue is the measurement of the influence of particular network measures on the efficiency of nodes, as well as the whole system. These issues are dealt with by network analysis, which uses SNA (Social Network Analysis) 
methods (Knoke \& Yang, 2020; Scott, 2017). The network analysis method is distinguished from conventional social research tools by the fact that its focus is on the so-called relational data, not attributes. This method allows one to study complex multi-element and multi-level structures of relations between different types of social entities and uses graph theory to study social phenomena. Using data about relations, network analysis allows one to study the structure of relations between individuals, as well as the dependence of the structure on the attributes of individuals and the impact on processes that occur through relationships (transactions, information flow, cooperation) (Batorski, 2008; Knoke \& Yang, 2020). For example, in organizational research, the analysis of the structure of communication in an organization can identify informal relationships, the importance of individual units for information and knowledge flows, as well as identify informal leaders (Kilduff \& Tsai, 2003). Currently, the analysis of social networks is a tool rooted in the tradition of many disciplines (e.g., mathematics, sociology, anthropology, statistics, etc.). Among others, the following researchers and experts are considered to be the main creators and promoters of SNA: Stanley Wasserman, Steve Borgatti, Philippe Bonacich, Berry Wellman, Linton C. Freeman, Valdis E. Krebs, Mark Granovetter, David Knoke, and Rob Cross.

The development of the network approach was significantly influenced by research on scale-free networks and small-world networks. In the 1990s, Hungarian physicist Albert-László Barabási discovered that a number of networks (from the Internet, through the cellular metabolic system, to the network of connections between Hollywood actors) are dominated by a relatively small number of nodes connected to many other points of the network.

In the literature on organizational networks, apart from the terms networking, network approach, the term "network paradigm" appears which means abandoning the unrealistic assumption of atomization of the enterprise environment in favor of structuralism. The network paradigm takes over the postulates of structuralism, explaining the embedding of every business activity in the systems of social relations. According to the authors, the key significance of the network paradigm is to discover a certain structural order in social networks. On the one hand, this means the need to consider the network as a context for action, and on the other hand, it implies methods of learning about the network. This network order can be measured, parameterized, and studied with the help of social networks analysis. It affects the very possibility of action, which is not the same for individual actors, and the effects of their actions. It reveals the privilege of some actors and the advantage of some types of networks over others (Czakon, 2012; 2016: Knoke \& Yang 2020; Scott, 2017). 
The broader context for considerations on the network approach is the concept of "network science." Network science, whether it is rooted in the social sciences, computer science, or the natural sciences such as physics or biology, has three general, interrelated, and ongoing goals: (1) to measure, describe, and categorize network structure and the patterns of relationships between network nodes; (2) to understand network evolution and growth and its relationship to network structure; and (3) to understand how the collective behavior of entities connected in a network depends on and derives from the network's structure. Many open questions exist at all three levels. The overall intuition behind the interdisciplinary conversations that characterize "network science" is that common structures, growth patterns, and collective behaviors will arise in networks composed of very different kinds of elements and linkages. If this is the case, common concepts and methods will be useful in understanding widely varying networks and in answering the very different substantive questions posed by physicists, biologists, computer scientists, sociologists, and, most recently, by organization, management and strategic management (Strandburg et al., 2006).

The above considerations show that the possibilities of exploring network theory are very large. This applies to many disciplines, including management and social sciences. The research areas presented are interdisciplinary and amorphous. Many concepts are emerging, which proves that the coming years will be associated with the further development of the network approach.

\section{Theoretical basis of network research in strategic management}

One of the important issues, which enable the formulation of rules for the creation, functioning, and management of organizational networks, is to indicate the theoretical basis of the network concept. Therefore, it is necessary to search for possible links with a large number of theories and methodological schools. The most frequently used theoretical bases in network research in strategic management are the theories of embeddedness, resource, resource dependence, social capital, and industrial networks. It is worth noting that these theories can be used for both emergent and intentional networks research (Światowiec-Szczepańska \& Kawa, 2018).

Sources of network origin, particular processes taking place in them, coordination issues and the mechanism of network functioning are closely related to certain specific theories. It seems that the research theories related to the network issues can be arranged as follows (Table 1).

In the context of the cited network theories, it is easier to understand the ongoing discussion in the literature concerning the network theory itself. The most common thesis is that there is no universal network theory, 
and individual network models have their foundation in different theories. Światowiec-Szczepańska and Kawa (2018) indicate four areas of research: contamination, convergence, capitalization, and position in the network.

Table 1. Theories underpinning the development of the network concept

\begin{tabular}{|c|c|c|c|}
\hline Economic theories & $\begin{array}{l}\text { Social (sociological) } \\
\text { theories }\end{array}$ & $\begin{array}{l}\text { Modern theories in } \\
\text { management sciences }\end{array}$ & $\begin{array}{l}\text { Mathematical } \\
\text { approach }\end{array}$ \\
\hline $\begin{array}{l}\text { - transaction cost } \\
\text { theory } \\
\text { - contract theories } \\
\text { (the contents of } \\
\text { the "black box" are } \\
\text { analyzed) } \\
\text { - ownership theory } \\
\text { - contract theory } \\
\text { agency theory } \\
\text { - corporate } \\
\text { governance } \\
\text { - game theory }\end{array}$ & $\begin{array}{l}\text { - embeddedness } \\
\text { theory (including } \\
\text { relational } \\
\text { embeddedness } \\
\text { theory) } \\
\text { - functional and } \\
\text { structural theory } \\
\text { - interactive } \\
\text { approach } \\
\text { - sociological } \\
\text { concept of social } \\
\text { network } \\
\text { - analysis of social } \\
\text { networks } \\
\text { - actor-network } \\
\text { theory } \\
\text { - relational capital } \\
\text { theory }\end{array}$ & $\begin{array}{l}\text { - } \text { resource theory } \\
\text { - capital concept } \\
\text { - resource } \\
\text { dependency theory } \\
\text { - } \text { the concept } \\
\text { of knowledge } \\
\text { management } \\
\text { - the concept of } \\
\text { organizational } \\
\text { learning } \\
\text { - cognition theory } \\
\text { - complexity theory } \\
\text { - quota theory } \\
\text { - business ecosystem } \\
\text { theory } \\
\text { - institutional theory } \\
\text { (institutional } \\
\text { - isomorphism) } \\
\text { - industrial network } \\
\text { theory }\end{array}$ & $\begin{array}{l}\text { - graph theory } \\
\text { - scale-free theory } \\
\text { - small-world theory } \\
\text { - structural gap } \\
\text { theory } \\
\text { - theory of weak/ } \\
\text { strong ties } \\
\text { - complex systems } \\
\text { theory }\end{array}$ \\
\hline
\end{tabular}

Research in the area of contamination (diffusion and adaptation) is based on theories of: learning and innovation, cognition, business ecosystem, in the area of convergence: industrial network theory, small-world theory, structural equivalence theory, in the area of capitalization: resource theory, deposition theory, relational capital, structural gap, weak/strong bonds and in the area of position in networks: graph theory, scale-free theory, small worlds theory, structural gap theory.

Literature analysis reveals that only a few researchers, mainly from two research areas, (1) IMP's theory of industrial networks (Håkansson \& Snehota, 1995; Sashi, 2021) and (2) strategic network research (Czakon, 2012; 2016; Gulati, Nohria, \& Zaheer, 2000; Jarillo, 1988; Niemczyk, 2013; Wynstra, 1994; Kosch \& Szarucki, 2020; Hettich \& Kreutzer, 2021) address the issue of a strategic perspective in inter-organizational networks. This phenomenon is already addressed by the issue of a strategic perspective in inter-organizational networks. In line with the approach represented by the IMP Group's mainstream research, the creation of a business network and network connections does not constitute an active implementation of the 
strategic plan of one main company. However, the principle of the strategic equivalence of entities is far removed from economic reality. Often, among entities connected by relationships, a dominant company (or companies) can be distinguished in this respect, and companies increasingly consciously create business networks focused around themselves. Such relationships illustrate the strategic approach to the creation of networks. In contrast to the IMP Group's mainstream research, the strategic approach emphasizes that there is usually one main actor supervising, managing, and creating the network strategy (the so-called network leader - hub firm, network captain). The resulting strategic network ${ }^{4}$ has more formal links than the business network described by the IMP Group. More formal links do not exclude the importance of informal relations (Ratajczak-Mrozek, 2010). The direction of linking the idea of network and strategic management is therefore still emerging and rather amorphous.

\section{The main problems of the network concept in strategic management}

Networks have become a widespread concept, both in social and economic life. For this reason, some authors have considered it as "defining the paradigm of the modern era" (Kilduff \& Tsai, 2003, p. 13) or as the "dominant metaphor of our times" (Clegg, Josserand, Mehra, \& Pitsis, 2016, p. 278). There is no doubt that the network concept has achieved great popularity in recent years and is used in various research areas in management. Currently, the literature on inter-organizational networks is vibrant, and many authors are trying to define principles describing a "coherent" understanding of the network approach and theory as one of the disciplines of network science. This science has achieved significant development in the 21st century and has become one of the most active interdisciplinary research areas according to the principle that "networks are everywhere" (Barabási, 2016; Christakis \& Fowler, 2011; Newman, 2010). However, it is not entirely certain that the research conducted so far has contributed to the development of a coherent network theory. It seems that its existence is not a foregone conclusion but rather that it is in the development and testing phases. It is also questionable whether there is a consensus in the management sciences on what the network actually is, or whether it should be assumed that the network may have different meanings in different contexts. The main reason for this seems to be the interdisciplinary nature of this concept. The concept of

\footnotetext{
4 Strategic networks are long-term, targeted agreements between independent but affiliated organizations that enable them to gain or maintain a competitive advantage over companies outside the network (by optimizing operating costs and minimizing coordination costs). The concept of a strategic network clearly follows the network approach, in line with the IMP Group's current approach, breaking only with some of its assumptions, such as the absence of a dominant entity and the non-strategic selection of affiliate partners.
} 
'networks' is currently a central issue in many fields, including social sciences, communication, computing, physics, and even biology and ecosystems (Dorogovtsev \& Mendes, 2003; Barabási \& Bonabeau, 2003).

The importance of network science can be considered from the point of view of the emergence of a new paradigm, introduced by Kuhn (1962) as a set of concepts and theories that form the basis of a given science. The aforementioned researcher indicated that science is undergoing periodical paradigm changes. One can risk a claim that today we are witnessing such a change and the emergence of network science as a scientific discipline (Lewis, 2011). This emergence is mainly inspired by empirical research on networks in the real world, including technological networks (Balthrop, Forrest, Newman, \& Williamson, 2004; Gemünden \& Heydebreck, 1995), biological networks, information networks (Wellman, 2001) and social networks (Scott, 2017; Wasserman \& Faust, 1994: Knoke \& Yang 2020) and the discovery of common principles that govern them (Ujwary-Gil, 2020; 2019).

The growing popularity of network organizational solutions has led some researchers to see them as the dominant feature of the new paradigm also in strategic management. The presence of the network as a new model of competitiveness and value creation research has given rise to the consideration of the network paradigm (Batorski \& Zdziarski, 2009; Borgatti \& Foster, 2003; Czakon, 2012; Hettich \& Kreutzer, 2021). The literature points to the rationale for moving away from strategic management towards strategic "shaping the network" (Bowman, 2000, p. 35), as well as the need to change the branch and resource concept to understand the strategy as a "portfolio of inter-organizational relationships" (Dyer \& Singh, 2004). However, it should be noted that the legitimacy of this type of postulate has not been so far confirmed by empirical research.

The current state of research on organizational networks in strategic management theory shows that this approach is already quite well established. Analysis of the results of research conducted after 2000, relating to the conceptualization of strategic aspects of the network (Krzakiewicz, 2013; Wang, Yang, \& Guo, 2021; Wang, Chen, \& Fang, 2021; Jussila, Mainel, \& Nätti, 2016) indicates that there are certain limitations in the discussed scope:

1) Despite many attempts, no generally accepted definition of the concept of network organization has been developed. The analysis of studies representing such sciences as economics, management sciences, sociology, psychology of organization, ecology allows us to conclude that this large variety of approaches translates into difficulties in making a precise definition. 
2) The network's competitive advantages and competitive advantage annuities have become the subject of discussion in the literature on strategic management. However, the first attempts to study the strategic aspects of the network's functioning have already indicated the existence of significant theoretical problems. First of all, a contradiction has emerged between the underlying rationale of team-based managers and managerial control and the need to operate on the basis of cooperation and agreements (negotiations) in the process of creating and managing networks (Krzakiewicz, 2013; Wang, Chen, \& Fang, 2021). Secondly, the existing paradigms relating to the ways in which companies' strategies are examined proved to be insufficient. The approach to analysis from the position of the sector structure, developed by M. Potter, was quickly rejected as not very useful from the perspective of the reality of network structures; also the traditional resource-based approach, in which the basic unit that is analyzed is not the sector, but individual entities operating in the sector, proved not fully useful. According to the resource concept, competitive advantages are within the organization, whereas according to the network structures, the network actors do not try to hide their individual competencies and skills from the rest of the participants, and assets are allocated within the network, due to the pursuit of synergistic business potential.

3) The consequence of modern competitive conditions is the need for organizations to complement their internal competencies with as many external relations as possible. The above assumption was formulated within the concept of strategic management as a "portfolio of relations." It seems, however, that the concept of a "portfolio of relations" can be treated in terms of complementing the preceding concepts of a "business portfolio" and "capacity portfolio." These three concepts point to a separate source of creating competitive advantages - the stage of evolution, economies of scale and diversity, and diversity of expertise, respectively ${ }^{5}$. However, the creators of the concept of the strategy as a "portfolio of relations" admit that it has not yet gone beyond the considerations of defining its distinctive characteristics. However, the basic principles of building inter-organizational networks have not been defined, it is not clear how to conceptualize a business structure that is embedded in a specific organizational system, what possibilities this concept provides in terms of explaining differences between companies and how to measure the competitive advantage shaped by networks (Venkatraman \& Subramaniam, 2002; Krzakiewicz, 2013; Wang, Chen, \& Fang, 2021).

4) A certain difficulty in interpreting the income generated by networks and in the network is caused by the location of the reference point (in the

5 The concept of economy of expertise is related to the benefits that a company obtains due to its central position in the network, which provides it with privileged access to sources of knowledge created in the network. This makes the inter-organizational network the object of strategic management research. 
context of network solutions, however, the problem of generating added value from a wider perspective than just that of the individual parties to the contract very often arises) and additionally the dynamics of the business processes themselves is too high.

5) A particular problem related to the perception of organizational and interorganizational networks is the definition of what is inside an organization and what can be considered as its environment. The boundaries of the network are fluid; the boundaries of the network are blurred.

6) Network learning is associated with a number of additional, current challenges (Kocarev \& In, 2010; Wang, Yang, \& Guo, 2021), relating to how to draw conclusions from network data (e.g., how to characterize the network, its structure and properties; what are the processes that take place in networks). These challenges are related to a number of problems, such as the problem of missing links in the network or understanding the dynamics of processes taking place in the networks. There are almost as many dynamic phenomena as there are networks. However, our understanding of the flow mechanisms, long-term dynamics or interdependencies in the network is still far from being clear.

\section{Towards a network approach to strategic management}

In the context of the above considerations, it can be concluded that the key issue in the framework of the network approach is to indicate its consequences for the definition of the strategy. In the most general sense, a strategy always refers to the objective and the means by which the objective will be achieved, and can therefore be considered a fundamental part of any company. The approaches described so far have pointed out various determinants of the strategy. In the case of the planning approach, the archetype of strategy was the question of the scale of market or product development. In the positional approach, the company could beat the competition with a lowcost or differentiating strategy. In the resource approach, the basic dilemma was about competence development in relation to market development. The innovative and entrepreneurial approach, on the other hand, indicated an opposition in the form of activation in the blue ocean or a conservative attitude in the red ocean (Niemczyk, 2012). The exploration of the network approach in strategic management allows us to adopt the category of network strategy, which can be described through the coexistence of cooperation and competition. Starting from the assumptions of the relational and network approach, network strategy can be defined as a continuous and dynamic process of choices concerning the establishment, development, as well as withdrawal from inter-organizational relations, made under conditions of uncertainty (limitations, pressures, and opportunities) to: 
- maintain and develop the capacity of the organization;

- create and capture the value;

- receive a relational annuity and widely understood benefits from network cooperation.

It is also a process of continuous strategic choices:

- selection of key partners (competing and/or non-competing);

- the way the relationship is created (intentional and/or emergent);

- the dynamics of the relationship (decisions about their establishment, development or withdrawal, the duration of the relationship, the intensity of the relationship, the nature of the relationship: concentration on cooperation and/or coopetition);

- how to create value and capture it.

The network strategy should also specify:

- the company's internal resources and competences;

- expectations towards external organizations;

- the type of external links that will provide access to the required resources and competences.

Such a strategy implies that an organization is an intentional and entrepreneurial entity with a unique specialization of resources and competences, acquiring external resources and competences and developing interactions with other organizations. There are strategic conflicts within a network organization when network actors pursue their own goals and have their own perception of the network and the parties interacting.

From a network perspective, business strategy plays an important role in guiding the development of individual relationships and networks. The business strategy must take into account the interdependencies between actors who are linked by direct or indirect relationships (Juttner \& Schlange, 1996; Hernandez \& Menon, 2021). The resources and competencies that provide the existing portfolio of relations and ways of developing and using it are vital here. Furthermore, the business strategy must be expressed in terms of potential changes in the network in which the company operates, taking into account its current and selected position in the network (Johanson \& Mattsson, 1992; Kumar \& Zaheer, 2019).

Due to interdependencies and the mechanisms of change and dynamics in the networks (Håkansson \& Snehota, 1995; Hedvall, Jagstedt, \& Dubois, 2019; Hettich \& Kreutzer, 2021), it can be said that it is not only strategy that influences the development of an organization. An organizational network also influences business strategy. Many of a company's strategic choices and actions are a response to the actions of other companies (Ford et al., 1998) 
and changes in the network of relations. The company's strategy and the network of relations are interconnected.

It is worth noting that so far network research has focused primarily on recognizing the benefits of inter-organizational collaboration, indicating that collaboration and coopetition contribute to achieving synergistic effects, gaining access to resources, their exchange or general improvement of the organization's performance and efficiency through collaboration (Ritala, Ellonen, 2010; Czakon, 2012; Kobayashi, 2014; Hettich, \& Kreutzer, 2021). Meanwhile, inter-organizational cooperation may also result in the loss of potential opportunities or destruction of values. Therefore, the implementation of a network strategy may not only bring benefits, but is also associated with negative effects, risks, and costs (Alders, Van Liere, Berendsen, \& Pieters, 2010; Mitręga \& Zolkiewski, 2012; Hernandez \& Shaver, 2019; Jussila, Mainela, \& Nätti, 2016).

Summarizing the above considerations, one can point to several conclusions:

- the analysis of the literature shows that the attempts to conceptualize the strategic aspects of the network bring a significant impact on the development of research on organizational networks, but the analyses and research reveal many shortcomings resulting mainly from the narrow treatment of the problem from the perspective of individual disciplines;

- the use of the network approach in strategic management theory allows for a better understanding of the strategic behavior of modern companies;

- particularly important for the development of a network approach in strategic management is the combination of an organizational and economic approach with a logic of competitive advantage and relational annuity;

- the network approach in strategic management should be more explicit about how organizations can use their belonging to an inter-organizational network to increase their competitiveness and competitive advantage, as well as the strategic actions needed to achieve strategic success;

- although many researchers seem to have touched on this area, aspects of the mutual, very important exchange between the strategy and the network still need to be explored.

\section{Contributions}

The authors of the papers submitted and accepted in this special issue of JEMI addressed emerging trends, research concepts, problems, and challenges 
that refer to the contemporary approaches to the network perspectives in strategic management.

In this issue, the collection of articles shows how different and distant the research fields can be in which the concept of network approach is applied in strategic management. Our scholars cover areas such as: a review of the literature on networks and network strategies to develop a new theorization based on a systematic review of the literature; the seeking of another research path to examine the contribution of networking to strategic management; the definition of the network of scientific and technological policies in the form of social networks; virtual reality and its synergistic effects in network interconnections; the development of an economic model that connects strategic management and network theory; the notion of network resource distribution to study how business resources and network structure work together to influence business performance.

All the articles present the findings of both conceptual and empirical research, in this last case conducted with the use of both qualitative and quantitative research methods and with the application in different countries such as the USA, Iran, and the Czech Republic.

The article by Rossella Canestrino and Amir Forouharfar introduces a broad all-embracing taxonomy of networks and its relevant strategies to make easy and efficacy the learning and teaching of the basic concepts of networks in strategic management. The research was conducted by a systematic literature review (SLR), on the assumption that the introduced taxonomy and its corresponding strategies should represent the synthesis of the current literature in the studies on strategic networks. As a result, the research focused and revealed seven potential configurations of the networks and then the proposition of their relevant strategies with regard to the networks' relationships and forms. These networks are as follows Reciprocally Interdependent Networks, Sequentially Interdependent Networks, Partnering Networks, Complementary (Overlapping) Networks, Supporting (Logistic) Networks, Distributing Networks, and Co-Innovation Knowledge-Sharing Networks and, at the same time, their corresponding network strategies were identified as Multi-Level Promotion Strategy, JustIn-Time Strategy, Network Partnership Strategy, Compensatory Strategy, Network Logistic Strategy, Distributing Network Strategy and Network R\&D Strategy respectively. From the point of view of the implications for theory and practice, this paper helps all scholars through a comprehensive and concise means of systemizing and classifying networks and their own strategies in an attempt to bridge an existing gap in literature: these efforts invite future research and conversation about networks and network strategies. Based on completed studies, a conclusion can be formulated that inspiration for their 
research is the lack of consensus on theories and conceptualizations in the study of strategic networks.

The intent of Nancy J. Miller, Carol Engel-Enright and David A. Brown's research is to fill some of the gaps in interorganizational networking strategy by analyzing five antecedents that have been suggested in the literature as individually associated with entrepreneurs' engagement in network ties. As the activities of others influence each firm and thus all direct and indirect relationships shape and influence the firm's strategic management, these relationships are key to accessing and creating knowledge and other strategically important resources. Research work is framed by the resourcebased view of the firm perspective and social capital theory and its shared constructs in network theory. In this way, it provides another research avenue for examining networking's contribution to strategic management. By a quantitative approach, the research group tested their proposed macrolevel direct and moderating connections through an online survey of 125 U.S. apparel manufacturing firms to confirm their hypothesized connections, even if, when all five were collectively examined only three of them - absorptive capacity, social interaction, and business goals - were significant. So, the research's results were that the effects of a supportive environment on the relationship between business objectives and network links were more intense when perceptions of a supportive environment decreased, while the effects of a supportive environment on the relationship between entrepreneurship orientation's and network links were greater when perceptions of a supportive environment increased.

Defining the science and technology policy network in the form of a social network and then analyzing it using the social networks analysis (SNA) method is the main goal of Esmaeel Kalantari, Gholamali Montazer and Sepehr Ghazinoory's paper. They analyzed the science and technology policymaking network in Iran using the content analysis of 25 policy documents and an interview with 20 Iranian science and technology policy elites: then they were interpreted by NetDraw and UCINet. As result, performing a twodimensional core-periphery analysis, identifying the cut points and blocks, and measuring the structural power of each institution using the degree centrality, closeness centrality and betweenness centrality methods, the authors revealed that the most head science and technology policy-making institutions in Iran and their interactions were determined from the network viewpoint. The most prominent practical implications of this research are: the integration of some policymaking institutions, the precise allocation of roles and competences between the policy institutions, the definition of vertical and horizontal coordination mechanisms between the institutions, the elimination of overlaps in the tasks between some institutions, the design 
of complementary mechanisms for monitoring the role of cutting points and attention to important activities in the margins of the network. The originality and value of this research are first to define a framework for studying science and technology policy and, after that, develop a method for studying science and technology policy based on SNA.

Kateryna Kraus, Nataliia Kraus, Olena Shtepa bring us into virtual reality conditions to spread the synergistic effect as a consequence of the network interactions of the development institutions in the new virtual economic reality and explain their relationships through knowledge of the functioning of clusters. Using the institutional-network approach, the characteristic features of cluster formation network interactions in virtual reality conditions are studied and, at the end of research activities, the authors stated that the synergistic effect of networking creates a new phenomenon of marginal growth utility and increasing marginal productivity from innovative glocalization and digital globalization: so the greater the scope of innovation and digital activities in virtual reality conditions is, the greater the efficiency of the use of additional resources is. The implications are to demonstrate that the synergistic approach used in the formation and development of innovation-digital clusters is considered through the prism of the relationship "subjective - subjective relationship of innovation organisations and digital enterprises" and, in this case, the effect lies in the restructuring plan of the "old" development institutions in the "new" ones. Understanding the content of the network economy, an economy in which activities are carried out using electronic networks, is an element of originality. The basis of this economy are network institutions, entities, organizations and, moreover, they create an environment in which any business entity or individual has been able to communicate easily and at minimum cost.

The article by Martin Pech, Drahoš Vaněček, and Jaroslava Pražáková addresses, from the network point of view, the problem of complexity, continuity, and strategic management of buyer-supplier relationships. The paper aims to analyze and study, referring to firms' dimensions and sectors to which they belong, the connection and relation between enterprise characteristics and characteristics of buyer-supplier relationships in supply chain networks. Using a quantitative method, they collected data during the period 2016-2019 in the Czech Republic through an online and personal survey to the firms and, at the end of the process, they used a two-proportion Z-test to compare different categories of firms in line with the above. Research showed that there are no differences in industrial sectors but only in their size: in the Czech Republic, the complexity of networks is low and long-term relationships are preferred. At the same time, bigger firms adopt contracts for more or less short periods. Starting from the assumption that there is 
a connection of supply chain management and strategic management from the network perspective, and that supply chain management is viewed as being a part of strategic management, the paper helps in understanding how the buyer-supplier network works and the value of the relation between contemporary ideas of strategic management and supply chain management.

The issue of the network approach was also discussed in the article by Jesse Karjalainen, Aku Valtakoski, and Ilkka Kauranen. This conceptual paper starts from existing and available literature about interfirm networks and then develops the unifying concept of network resource distribution with the aim to suggest the notion of network resource distribution that allows an integrated study of how business resources and network structure work together to influence and improve business performance. Although strategy scholars have worked long and hard to combine the resource-based vision and the social network explanations of firm performance with poor and partial results, the suggested concept of network resource distribution systematizes prior research activities and highlights how network structure and firm resources interact with each other to affect and improve firm performance regardless of the closer network partners. The theoretical and practical implications of this research are, firstly, to illuminate the shortcomings in the literature on interfirm networks and suggest unique solutions to solve this problem and update and enrich the theory and, secondly, to prevent managers from limiting their strategic alliances to immediate partnerships. The topics covered are new concepts that bind and systematize different lines of research on intercompany networks, thus providing a basis for future research in this area.

\section{Further research}

The presented problems as well as research related to network approach exploration in strategic management, enrich the present knowledge in this area, but also indicate further directions of exploration, creating inspiration for other researchers and management practitioners. Network approach is a branch of management science that is constantly being developed. Changes in the environment of enterprises create new challenges in this area and contribute to the creation of new concepts of network approach in management. Classic methods are also perfected to increase their effectiveness. This special issue of JEMI presents selected current problems in the development of network approach exploration in strategic management concerning both the development of known concepts and methods of network strategic management, as well as new ones. The conducted research provided new knowledge in the discussed problems and allowed to set the directions for further research. 
Lack of consensus about theories and conceptualizations in strategic network studies became an inspiration for Rossella Canestrino and Amir Forouharfar's research, which allowed them for the clarification of the existing paucity mentioned. The authors of the article: Networks and Network Strategies: New Theorization Based upon Systematic Literature Review presented a literature-supported systematics classification for the strategic studies of networks and introduced network taxonomy and its related network strategies. In their opinion, more research is needed using more articles and databases, to compensate for the potential shortcomings of the research in this field, done so far.

The contribution of the article by Nancy J. Miller, Carol Engel-Enright, and David A. Brown is in the examination of how an organization's decisions may relate to engaging in networks. This research provides new insights into the benefits of directing efforts to engage in network ties as a strategy managing market challenges. In their opinion, further research in this area should concern, for example, further integration of social capital and network theory with other leading perspectives in management research (e.g., institutional theory or resource dependence theory), the interaction effect between entrepreneurial orientation and perceptions of a supporting environment in relation to firm engagement in network ties or the interaction among business goals and supporting environment perceptions in relation to network tie engagement.

The paper's main purpose by Esmaeel Kalantari, Gholamali Montazer, and Sepehr Ghazinoory was to define the science and technology policy network in the form of a social network, from the perspective of policy documents, and then analyzing it using the social networks analysis (SNA) method. The most pivotal science and technology policy-making institutions and the interactions between them were determined from the network viewpoint. The authors noted that sometimes policy documents are different from what is happening in reality. Therefore, in future research, they recommended to analyze the science and technology policy network in reality, for example, based on mere interviews with experts, and compare and analyze the differences between that network and the document-based network.

Kateryna Kraus, Nataliia Kraus, and Olena Shtepa's research noted that the network economy in the XXI century, like no other economy (innovative, informational, knowledgeable, blue, green, circular, row, digital), highlights the organic relationship of technological (virtual-real networks) and institutional specifics of a constantly updated way of life (networked social environment). They stressed that the formation of a new quality of networking and cooperation is a new approach to solving the problem of competition in virtual reality and in digital market of goods/services. In their opinion, it is 
still important in the future to conduct research aimed at understanding the ideology of a digital economy, in order to form a new virtual reality and to find the answers to the following questions: How is virtual reality different from digital, augmented, and mixed realities? How is it possible to work in a digital ecosystem with an innovation ecosystem? How can digital entrepreneurship, start-up, and the state "in the smartphone", influence the development of innovations and derive economic benefits from it?

The business relationships in networks with respect to the various enterprises' sizes and sectors of industry were analyzed in the research done by Martin Pech, Drahoš Vaněček, and Jaroslava Pražáková. They show an empirical study on buyer-supplier networks and accentuate the importance of developing and fostering business collaboration for strategic management. In their opinion, the strategic management of networks is a current challenge in network research, and the future research directions should be related to the conditions, factors, and variables that affect the division of roles and power networks. The authors' potential area for further research is applying and using new technologies (such as blockchain) that virtualize relationships and connections into a digital form.

The authors of the article: Interfirm network structure and firm resources: Towards a unifying concept, Jesse Karjalainen, Aku Valtakoski, and Ilkka Kauranen, proposed a unified concept of network resource distribution that systematizes prior research and illuminates how network structure and firm resources interact to affect the firm performance beyond the immediate network partners. The network resource distribution concept opens new and significant opportunities for researchers to contribute to the survey on interfirm networks and firm performance. In the authors opinion, many further theoretical issues in this field need to be investigated in the future to find answers to the following questions: How does the network configuration at the network node level-the resource mix and the resource characteristics-affect the optimal shape of network resource distributions? How do configuration choices at the relational level affect the optimal shapes of the distributions? In their opinion, it would be interesting to study how the optimal shapes of network resource distributions depend on the configuration choices made on the whole network level and how optimal distributions evolve over time. Future research could also seek to investigate how network resource distributions on various levels of analysis interact with one another.

We believe that the results of the presented research and analysis have certainly enriched network theory and research on the network approach in strategic management and will inspire other researchers and management practitioners. We postulate the need for further intensive research in the area 
of possibilities to explore the network approach in strategic management, indicating the directions and areas of potential research.

\section{Acknowledgment}

The publication was co-financed by a subsidy awarded to the Cracow University of Economics.

\section{References}

Achrol, R. S., \& Kotler, P. (1999). Marketing in the network economy. Journal of Marketing, 63(4), 146-163. https://doi. org/10.1177/00222429990634s114

Alders, B., Van Liere, M., Berendsen, G., \& Pieters, I. (2010). Risk in interorganizational networks and strategic alliances. Han Business Publications, 3, 27-39. Retrieved from www.han.nl/ hanbusinesspublications3

Ansoff, H. L. (1965). Corporate Strategy. New York: McGraw-Hill.

Balthrop, J., Forrest, S., Newman, M. E. J., \& Williamson, M. M. (2004). Technological networks and the spread of computer viruses. Science, 304 (5670), 527-529. https://doi.org/10.1126/science.1095845

Barabási, A. L., \& Bonabeau, E. (2003). Scale-free networks. Scientific American, 288(5), 60-69. https://doi.org/10.1038/amerykański naukowy0503-60

Barabási, A. L. (2016). Network Science. Cambridge: Cambridge University Press. Baum, J., \& Rowley, T. (2008). Network Strategy. Bradford: JAI Press Inc.

Barczak, B. (2016). Koncepcja Oceny Efektywności Struktur Sieciowych. Kraków: Wydawnictwo Uniwersytetu Ekonomicznego w Krakowie.

Barczak, B. (2020). Modele Sieci Organizacyjnych. Kraków: Wydawnictwo Uniwersytetu Ekonomicznego w Krakowie.

Batorski, D. (2008). Metody analizy sieci i ich zastosowanie w ewaluacji, In A. Haber \& M. Szałaja (Eds.), Środowisko i Warsztat Ewaluacji (pp. 167193). Warszawa: PARP.

Batorski, D., \& Zdziarski, M. (2009). Analiza sieciowa i jej zastosowanie w badaniach organizacji i zarządzania. Problemy Zarzqddzania, 7, 157-184.

Borgatti, S. P., \& Foster, P. C (2003). The network paradigm in organizational research: A review and typology. Journal of Management, 29(6), 9911013. https://doi.org/10.1016/S0149-2063_03_00087-4

Bowman, E. H. (2000). Strategy Change: Possible Worlds and Actual Minds. New York: Harper \& Row.

Castells, M. (2010). The Rise of the Network Society: The Information Age: Economy, Society, and Culture. Hoboken: Wiley-Blackwell.

Chandler, A. D. (1962). Strategy and Structure Chapters in the History of American Enterprise. Boston: MIT Press. 
Christakis, N. A., \& Fowler, J. H. (2011). Connected: The Surprising Power of Our Social Networks and How They Shape Our Lives. London: Harper Press.

Clegg, S., Josserand, E., Mehra, A., \& Pitsis, T. (2016). The transformative power of network dynamics: A research agenda. Organization Studies, 37(3), 277-291. https://doi.org/10.1177/0170840616629047

Czakon, W. (2017). Świadomość sieciowa w strategiach relacyjnych. Organizacja i Kierowanie, 2(176), 93-104.

Czakon, W. (2016). Network strategies logic. Problemy Zarzqdzania, 14/4(64), 17-30.

Czakon, W. (2012). Sieci w Zarządzaniu Strategicznym. Warszawa: Oficyna Wolters Kluwer business.

Dorogovtsev, S. N., \& Mendes, J. F. F. (2002). Evolution of Networks. From Biological Nets to the Internet and WWW. Oxford: Clarendon Press.

Dyer, J. H., \& Singh, H. (2004). The relational view: Cooperative strategy and sources of interorganizational competitive advantage. Academy of Management Review, 23(4), 660-679. https://doi.org/10.5465/ amr.1998.1255632

Ford, D., Gadde, L-E., Håkansson, H., Lundgren, A., Snehota, I., Turnbull, P., \& Wilson, D. (1998). Managing Business Relationships. Chichester: John Wiley \& Sons.

Gemünden, H.G., \& Heydebreck, P. (1995). The influence of business strategies on technological network activities. Research Policy, 24(6), 831-849. https://doi.org/10.1016/0048-7333(94)00784-5

Gulati, R., Nohria, N., \& Zaheer, A. (2000), Strategic networks. Strategic Management Journal, 21(3), 203-215. https://doi.org/10.1002/ (SICI)1097-0266(200003)21:3<203::AID-SMJ102>3.0.CO;2-K

Gupta, A. K., Govindarajan, V., \& Wang, H. (2008). The Quest for Global Dominance: Transforming Global Presence into Global Competitive Advantage. San Francisco: Jossey-Bass.

Håkansson, H., \& Snehota, I. (Eds.). (1995). Developing Relationships in Business Networks. London: Routledge.

Håkansson, H., \& Ford, D. (2002). How should companies interact in business networks?. Journal of Business Research, 55(2), 133-139. https://doi. org/10.1016/S0148-2963(00)00148-X

Hedvall, K., Jagstedt, S., \& Dubois, A. (2019). Solutions in business networks: Implications of an interorganizational perspective. Journal of Business Research, 104, 411-421. https://doi.org/10.1016/j.jbusres.2019.02.035 Herhausen, D., Morgan, R. E., Brozović, D., \& Volberda, H. W. (2021), Reexamining strategic flexibility: A meta-analysis of its antecedents, consequences and contingencies. British Journal of Management, 32(2), 435-455. https://doi.org/10.1111/1467-8551.12413

Hernandez, E., \& Menon, A. (2021). Corporate strategy and network change. Academy of Management Review, 46(1), 80-107. https://doi. org/10.5465/amr.2018.0013 
Hernandez, E., \& Shaver, J. M. (2019). Network synergy. Administrative Science Quarterly, 64, 171 - 202. https://doi.org/10.1177/0001839218761369

Hettich, E., \& Kreutzer, M. (2021). Strategy formation across organizational boundaries: An interorganizational process model. British Journal of Management, 32(1), 147-199. https://doi.org/10.1111/14678551.12473

Jarillo, J. C. (1988). On strategic networks. Strategic Management Journal, 9(1), 31-41. https://doi.org/10.1002/smj.4250090104

Johansson, J., \& Mattsson, L.G. (1992). Network positions and strategic action: An analytical framework. In B. Axelsson and G. Easton (Eds.), Industrial Networks: A New View of Reality (pp. 205-214). London: Routledge.

Jussila, A., Mainela, T., \& Nätti, S. (2016). Formation of strategic networks under high uncertainty of a megaproject. Journal of Business \& Industrial Marketing, 23, 203-215. https://doi.org/10.1108/JBIM-03-2014-0055

Jüttner, U., \& Schlange, L. E. (1996). A network approach to strategy. International Journal of Research in Marketing, 5, 479-494.

Kilduff, M., \& Tsai, W. (2003). Social Networks and Organizations. London: Sage.

Knoke, D. H., \& Yang, S. (2020). Social Network Analysis. London: Sage.

Kobayashi, M. (2014). Relational view: Four prerequisites of competitive advantage. Annals of Business Administrative Science, 13(2), 77-90. https://doi.org/10.7880/abas.13.77

Kocarev, L., \& In, V. (2010). Network science: A new paradigm shift. IEEE Network, 24(6), 6-9. https://doi.org/10.1109/MNET.2010.5634436

Kosch, O., \& Szarucki, M. (2020). Przegląd 25 lat europejskiej współpracy naukowej w dziedzinie zarządzania strategicznego: Analiza bibliometryczna. Europejski Przeglaqd Zarzqdzania, 18(1), 51-69. http:// dx.doi.org/10.1111/emre.12401

Kozarkiewicz, A. (2015). Sieci organizacji tymczasowych - nowa perspektywa badawcza w zarządzaniu portfelami projektów. Studia Ekonomiczne. Zeszyty Naukowe Uniwersytetu Ekonomicznego w Katowicach, 224, 83-95.

Krzakiewicz, K., \& Cyfert, Sz. (2013). The network concept of strategic management and its limitations. Management, 17(1), 19-30. https://doi. org/10.2478/manment-2013-0002

Krzakiewicz, K. (2013). Zastosowanie podejścia sieciowego w zarzadzaniu strategicznym. Organizacja i Zarzqdzanie, 1147, 109-118. https://doi. org/10.34658/oiz.2013.52.109-118

Kumar, P., \& Zaheer, A. (2019). Ego-network stability and innovation in alliances. Academy of Management Journal, 62, 691-716. https:// doi: 10.5465/amj.2016.081

Lewis, T. G. (2009). Network Science: Theory and Applications. New Jersey: Wiley Publishing.

Matyjas, Z. (2014). Podejście ekonomiczne w zarządzaniu strategicznym. Prace Naukowe Wałbrzyskiej Wyższej Szkoły Zarzq̨dzania i Przedsiębiorczości, 2, 139-152. 
Manning, S. (2017). The rise of project network organizations: Building core teams and flexible partner pools for interorganizational projects. Research Policy, 46(8), 1399-1415. https://doi.org/10.1016/j.respol.2017.06.005

Mitręga, M., \& Zolkiewski, J. (2012), Negative consequences of deep relationships with suppliers: An exploratory study in Poland. Industrial Marketing Management, 41(5), 886-894. https://doi.org/10.1016/j. indmarman.2011.09.023

Möller, K., \& Halinen, A. (1999). Business relationships and networks: Managerial challenge of network era. Industrial Marketing Management, 28(5), 413-427. https://doi.org/10.1016/S0019-8501(99)00086-3

Mouzas, S., Henneberg, S., \& Naudé, P. (2008). Developing network insight. Industrial Marketing Management, 37(2), 167-180. https://doi. org/10.1016/j.indmarman.2007.01.003

Nerur, A., Rasheed, A., \& Natarajan, V. (2008). The intellectual structure of strategic management field: An author cocitation analysis. Strategic Management Journal, 29, 319-336. https://doi.org/10.1002/smj.659

Newman, M. (2010). Networks: An introduction. Oxford: Oxford University Press. Niemczyk, J., Stańczyk-Hugiet, E., \& Jasiński, B. (2012). Sieci Międzyorganizacyjne. Współczesne Wyzwania dla Teorii i Praktyki Zarzqudzania. Warszawa: C.H. Beck.

Niemczyk, J. (2013). Strategia. Od Planu Do Sieci. Wrocław: Wydawnictwo Uniwersytetu Ekonomicznego we Wrocławiu.

Porter, M., (Ed.). (1986). Competition in Global Industries. Boston: Harvard Business School Press.

Ratajczak-Mrozek, M. (2010). Sieci Biznesowe a Przewaga Konkurencyjna PrzedsiębiorstwZaawansowanych TechnologiiNa Rynkach Zagranicznych. Poznań: Wydawnictwo Uniwersytetu Ekonomicznego w Poznaniu.

Ring, P. S., \& Van de Ven, A. H. (1992). Structuring cooperative relationships between organizations. Strategic Management Journal, 13(7), 483-498. https://doi.org/10.1002/smj.4250130702

Ritala, P., \& Ellonen, H. K. (2010). Competitive advantage in interfirm cooperation: Old and new explanations. Competitiveness Review: An International Business Journal, 20(5), 514-533. https://doi. org/10.1108/105954210101080751

Rumelt, R. P., Schendel, D. E., \& Teece, D. J. (1994). Fundamental Issues in Strategy. A Research Agenda. Boston: Harvard Business School Press.

Sashi, C. M. (2021). Digital communication, value co-creation and customer engagement in business networks: A conceptual matrix and propositions. European Journal of Marketing, 55(6), 1643-1663. https:// doi.org/10.1108/EJM-01-2020-0023

Schwab, K. (2016). The Fourth Industrial Revolution. New York: Crown Business. Scott, J. (2017). Social Network Analysis (4th ed.). London: Sage.

Strandburg, J. K., Csardi, G., Tobochnik, J., Erdi, P., \& Zalanyi, L. (2007). Law and the science of networks: An overview and an application to the 'patent explosion.' Berkeley Technology Law Journal, 21, 1293-1362. 
Światowiec-Szczepańska, J., \& Kawa, A. (2018). Metafory, modele i teorie sieci w naukach o zarządzaniu. Organizacja i Kierowanie, 2(181), 79-91.

Tikkanen, J., \& Halinen, A. (2003). Network approach to strategic management - exploration to the emerging perspective, paper presented at the 19th Annual IMP Conference. Retrieved from http://www.impgroup.org/ paper_view.php?viewPaper $=4430$

Teece, D. (2007). Explicating dynamiccapabilities:Thenatureand microfoudations of (sustainable) enterprise performance. Strategic Management Journal, 28(13), 1319-1350. http://dx.doi.org/10.1002/ smj.640

Ujwary-Gil, A. (2020). Organizational Network Analysis. Auditing Intangible Resources. New York: Routledge.

Ujwary-Gil, A. (2019). Organizational network analysis: A study of a university library from a network efficiency perspective. Library \& Information Science Research, 41(1), 48-57. https://doi.org/10.1016/j. lisr.2019.02.007

Wang, M., Chen, P., \& Fang, S. (2021). How environmental turbulence influences firms entrepreneurial orientation: The moderating role of network relationships and organizational inertia. Journal of Business \& Industrial Marketing, 36(1), 48-59. https://doi:10.1108/JBIM-05-2019-0170

Wang, J., Yang, N. \& Guo, M. (2021), Ego-network stability and exploratory innovation: the moderating role of knowledge networks, Management Decision, 59 (6), 1406-1420. https://doi.org/10.1108/MD-05-2019-0597

Venkatraman, N., \& Subramaniam, M. (2002). Theorizing the Future of Strategy: Questions for Shaping Strategy Research in the Knowledge Economy. London: Sage.

Vrdoljak-Raguž, I., Jelenc, L., \& Podrug, N. (2016). Neostrategic Management - An International Perspective on Trends and Challenges. Switzerland: Springer International Publishing.

Wang, M., Chen, P., \& Fang, S. (2021). How environmental turbulence influences firms entrepreneurial orientation: The moderating role of network relationships and organizational inertia. Journal of Business \& Industrial Marketing, 36(1), 48-59. https://doi.org/10.1108/JBIM-052019-0170

Wang, J., Yang, N., \& Guo, M. (2021). Ego-network stability and exploratory innovation: The moderating role of knowledge networks. Management Decision, 59(6), 1406-1420. https://doi.org/10.1108/MD-05-2019-0597

Wasserman, S., \& Faust, K. (1994). Social Network Analysis: Methods and Applications. Cambridge: Cambridge University Press.

Wellman, B. (2001). Computer networks as social networks. Science, 293(5537), 2031-2034. https://doi.org/10.1126/nauka.1065547

Wynstra, F. (1994). Strategic actions in networks - the concept of position. In W. Biemans \& P. Ghauri (Eds.), Industrial Marketing and Purchasing Group Conference (pp. 802-817). Retrieved from https://www.escholar. manchester.ac.uk/jrul/item/?pid=uk-ac-man-scw:2n462 
Zakrzewska-Bielawska, A. (2017). Seeking the content of the relational strategy: Conceptual framework. International Journal of Management and Applied Science, 3(4), 67-74.

\begin{abstract}
Abstrakt
CEL: Analiza literatury wskazuje, że próby konceptualizacji strategicznych aspektów sieci majq istotny wpływ na rozwój badań nad sieciami organizacyjnymi. Niniejszy artykuł ma na celu analizę nowych trendów w zarzq̨dzaniu strategicznym, a w szczególności możliwości eksploracji podejścia sieciowego w zarzqdzaniu strategicznym, poprzez istniejqca literaturę oraz prezentację nowych wkładów kolejnych artykułów opublikowanych w bieżqcym numerze. METODYKA: Artykuł ma charakter opisowy, dlatego bazuje na przeglqdzie literatury i jej konstruktywnej krytyce. Do przedstawienia głównych założeń i cech podejścia sieciowego w zarzqdzaniu strategicznym wykorzystano narracyjny przeglad literatury, wraz ze wskazaniem pojawiajqcych się trendów i nowych kierunków badawczych. Dokonano identyfikacji teoretycznych podstaw procesów zmian strategicznych w sieciach międzyorganizacyjnych oraz zaproponowano sposób rozumienia strategii sieci. WYNIKI: Badania zawarte $w$ tym numerze pokazujq, że z perspektywy sieci strategia biznesowa odgrywa ważnq rolę w kierowaniu rozwojem poszczególnych relacji i sieci. Eksploracja podejścia sieciowego w zarzqdzaniu strategicznym pozwala na przyjęcie kategorii strategii sieciowej, którq można opisać poprzez wspótistnienie współpracy i konkurencji. IMPLIKACJE DLA TEORII I PRAKTYKI: Rozważania prowadza do wniosku, że strategia biznesowa musi być wyrażona w kategoriach potencjalnych zmian w sieci, w której działa firma, z uwzględnieniem jej aktualnej i wybranej pozycji w sieci. Pomimo tego, że obecny stan badań nad sieciami organizacyjnymi w teorii zarzqdzania strategicznego wskazuje, że podejście to jest już dość dobrze ugruntowane, to na podstawie analizy wyników badań dotyczacych konceptualizacji strategicznych aspektów sieci, określono istniejqce problemy i zidentyfikowano ograniczenia. ORYGINALNOŚć I WARTOŚć: Wskazano główne problemy zwiqzane z badaniem podejścia sieciowego i wynikajqce z tego konsekwencje dla określenia strategii sieciowej. Wartość dodanq artykułu stanowi połaczenie podejścia organizacyjnego i ekonomicznego z logikq przewagi konkurencyjnej i renty relacyjnej. Wykazano, że perspektywa sieciowa w zarzqdzaniu strategicznym pozwala na pełniejsze zrozumienie strategicznych zachowań współczesnych przedsiębiorstw.
\end{abstract}

Słowa kluczowe: sieć, strategia sieciowa, podejście sieciowe, zarzq̨dzanie strategiczne.

\title{
Biographical notes
}

Beata Barczak is Associate Professor at the Cracow University of Economics, Department of Management Process. Her research interests focus on management sciences, project management, and organizational networks. She was the head of a research project concerning the assessment of the effectiveness of business networks. She is the author and co-author of over 140 scientific articles in the field of project management, management of organizational 
networks, innovation management, and modern management concepts. The most important publications are Measurement of centrality in organizational networks (2014), Problem of searching for borders of organizational networks (2015), Concept of assessment of network structures effectiveness (2016), Coordination of the project portfolio (2017), and Organizational network models (2020). She has participated in many research projects (NCN) and implementation projects, especially in the field of analysis and design of organizational structures (including business networks), management systems, analysis of organizational structures and processes in municipalities.

Tomasz Kafel is Associate Professor at the Cracow University of Economics, Department of Organization and Management Methods; the title of his postdoctoral dissertation/habilitation thesis is Methods of Professionalization in Non-Governmental Organisations. His research interests are focused on such areas as methodology of organization and management, strategic management, non-governmental organizations management, and creative thinking methods. He is the author and co-author of over 120 scientific publications in the form of monographs, articles, and conference materials.

Pierpaolo Magliocca is Associate Professor at the University of Foggia, Department of Humanities, where he teaches Operation Management, Strategic Management and Project Management, and is the Visiting Researcher at University of Jaén, Spain. He is a reviewer for the Journal of Knowledge Management, Journal of Knowledge Economy, and Sinergie, The Italian Journal of Management. His research interests focus on Knowledge Management, Firms Governance, and International Business. His activities are reinforced by his involvement in several academic research projects. He was scientific coordinator for the scientific project "Digital revolution and teaching methods," selected for funding by the University of Foggia. He is also involved in international collaborations and research projects about "Teaching Digital Entrepreneurship."

\section{Conflicts of interest}

The authors declare no conflict of interest.

\section{Citation}

Barczak, T., Kafel, T., \& Magliocca, P. (2021). Network approaches and strategic management: Exploration opportunities and new trends. Journal of Entrepreneurship, Management and Innovation, 17(3), 7-35. https://doi. org $/ 10.7341 / 20211731$ 
